\title{
The Skeleton Construction and Pharmaceutical Activity of Coumarins
}

\author{
Minrui Liu \\ College of Pharmaceutical Science, \\ Zhejiang University of Technology, \\ Hangzhou, 310014, China \\ e-mail: 31452721@qq.com
}

Jiachun Liu

College of Pharmaceutical Science, Zhejiang University of Technology, Hangzhou, 310014, China e-mail:474365898@qq.com

\author{
Zhanchao Zhao ${ }^{1}$ \\ College of Pharmaceutical Science, \\ Zhejiang University of Technology, \\ Hangzhou, 310014, China \\ e-mail:1006755759@qq.com
}

\author{
Gensheng Yang* \\ College of Pharmaceutical Science, \\ Zhejiang University of Technology, \\ Hangzhou, 310014, China \\ e-mail: yanggensheng@zjut.edu.cn
}

\author{
Wen Zhang* \\ College of Pharmaceutical Science, \\ Zhejiang University of Technology, \\ Hangzhou, 310014, China \\ e-mail:wzhang63@zjut.edu.cn
}

\begin{abstract}
Coumarins are oxygen-containing heterocyclic compounds, which is an important type of compounds in the discovery of bioactive molecules. Some work on the synthesis of bioactive coumarins has been done by other groups. Meanwhile, many synthetic methodologies have been put forward to construct skeleton of coumarins. Results: herein, typical methods constructing coumarin and its derivatives along with multifarious biological activity compounds in vitro and in vivo are summarized, which is of value for design, synthesis and biological application of coumarins.
\end{abstract}

Keywords-Coumarin; heterocyclic compound; synthesis; methodology; biological activity.

\section{INTRODUCTION}

Coumarins are well known as a kind of compouds containing a benzo- $\alpha$-pyrone mother structure (Fig. 1, type 1), all of which mostly come from the plants of the Rutaceae and Umbelliferae [1]. The first naturally occurring compound was isolated in 1820 [2]. Coumarins are separated into four categories: simple coumarins, furanocoumarins, pyranocoumarins, and the pyronesubstituted coumarins. The simple coumarins consist of a benzene ring modified by hydroxyl, alkoxy or alkyl groups and an $\alpha$-pyrone ring. The furanocoumarins, of which the coumarin nucleus are attached by a fivemembered furan ring, are divided into the linear furanocoumarins and the angular furanocoumarins. The pyranocoumarins is similar to the furanocoumarins, but five-membered furan ring is replaced with a sixmembered pyran ring, and the pyrone-substituted coumarins are one with substituents in the pyrone ring. These phyto-chemical derivatives, some interesting oxygen-containing heterocyclic compounds, exhibit the extensive biological activities due to biogenetical physiological active substance, 7-hydroxycoumarin (Fig. 1, type 2) [3]. To date, all the studies have indicated that coumarins possess a variety of biological activities, such as: anti-inflammatory[4], antimicrobial[5], antiviral[6], anti-oxidant[7], antinociceptive[8], anti-tumor[9], antiasthmatic [10], antidepressant [11], anti-HIV [12], antituberculosis [13], anti-Alzheimer [8], anti-influenza [14], antihyperlipidemic [15]. Due to their wide application in fragrance, agrochemical industries and pharmaceutical field, designing and synthesizing novel and potential coumarin derivatives is particularly important. In this paper, based on our recent study on coumarins, we summarize and analyze typical synthetic methodologies, including Knoevenagel, Perkin, Wittig and Horner-Wittig, Pechmann, Ponndorf, Baylis-Hillman, Wittig and Reformatsky methodology, Claisen rearrangement, as well as the Houben-Hoesch reactions, also give a brief introduction of coumarin derivatives on their biological activities.<smiles>O=c1occc2ccccc12</smiles>

1<smiles>O=c1occc2ccc(O)cc12</smiles>

2
Figure 1. The skeleton of coumarin and umbelliferone. 
II. A SUMMARY OF THE CLASSICAL SYNTHETIC METHODS OF COUMARINS

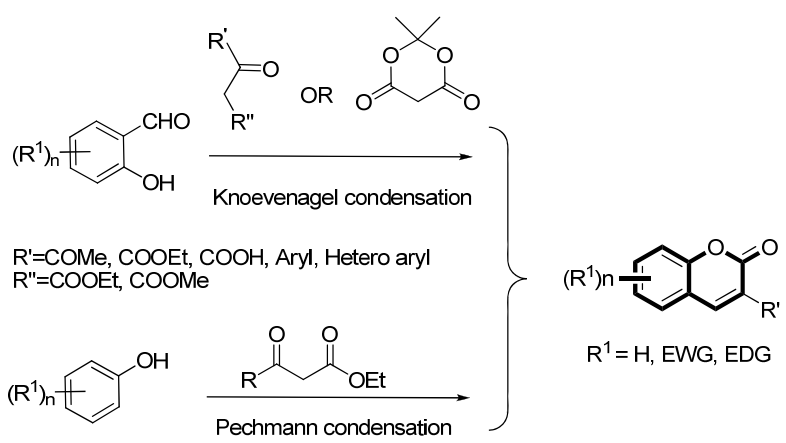

$\mathrm{R}^{\prime}=\mathrm{H}$, Aryl, Hetero aryl, etc

Figure 2. The Pechmann and the Knoevenagel condensations.

Cyclic condensation reaction of carbonyl compounds with phenol derivatives is a general method in organic synthesis. To obtain various types of coumarins, Knoevenagel [16], Perkin [17], Wittig and Horner-Wittig [18], Pechmann [19], Ponndorf [20], Houben-Hoesch [21], Baylis-Hillman [22], Wittig and Reformatsky methodology [23] have been used [24]. Also cylic condensation reactions include the condensation of $\mathrm{o}-$ hydroxyacetophenones with diethyl carbonate. Especially the Pechmann and the Knoevenagel condensations are widely used for the synthesis of coumarins with simple reaction conditions in good yield (Fig. 2). The Pechmann condensation is a simple and achievable method, starting from a phenol and a carboxylic acid or ester containing a $\beta$-carbonyl group. The reaction is performed under strong acidic condition without solvent, but this process is not environmentally friendly. The knoevenagel condensation is performed under much mild condition with a weakly basic amine. In addition, Claisen rearrangement [25] has a function of making the acetyl group intactly move on the benzene ring often used by many scientists (Fig. 3).<smiles>[R]=CCc1ccc(O)c2oc(=O)cc(C)c12</smiles>

Figure 3. The use of Claisen rearrangement in structural modification of coumarins.

Classical synthetic methods of coumarins are summed up as follows (Fig. 4).

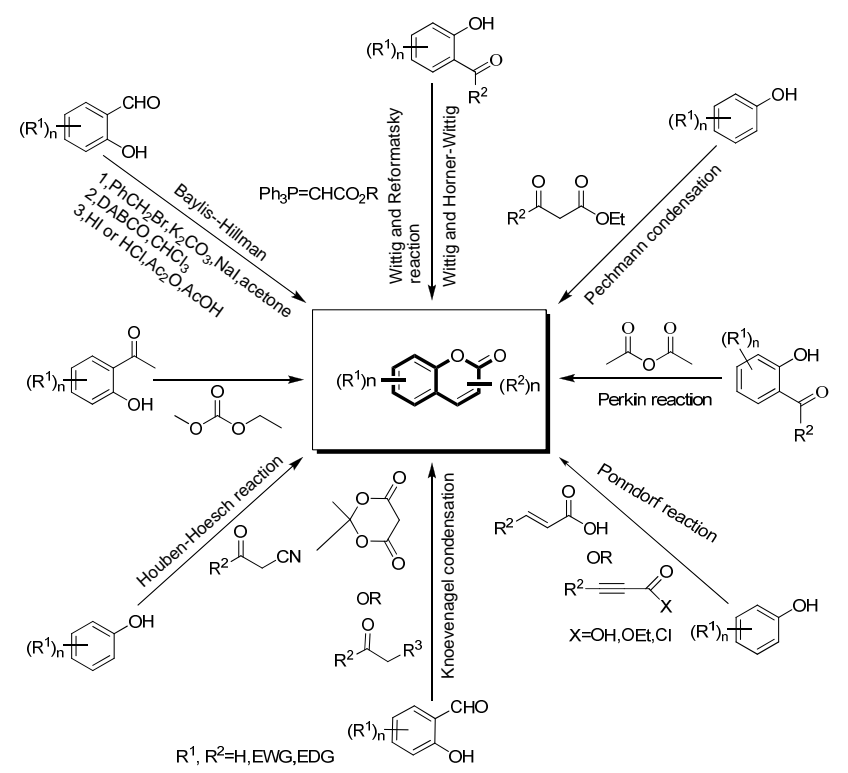

Figure 4. The synthesis of coumarins by various classical synthetic approaches.

In addition to above-mentioned chemical synthesis of coumarins, the skeleton construction of coumarins also include the biosynthesis of coumarins. The biosynthesis of coumarins is not yet well understood, but it is an effective way to synthesize coumarins. Herein, we simply show the biosynthesis of furanocoumarins. Umbelliferone is the parent compound of furanocoumarins [26] (Fig. 5).

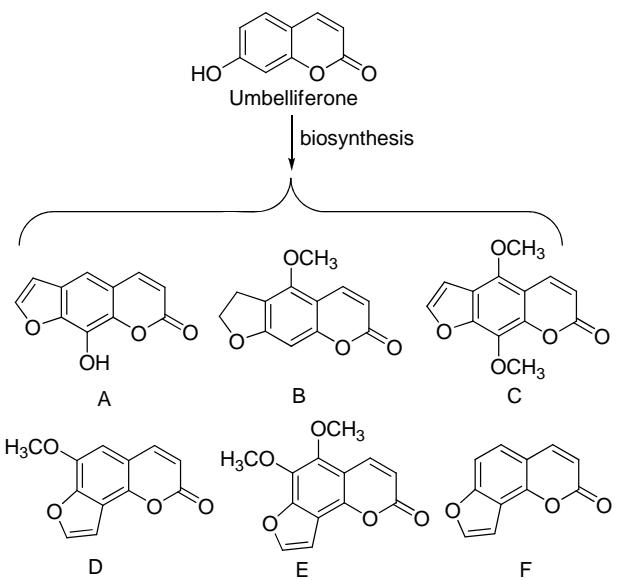

Figure 5. The biosynthesis of furanocoumarins.

\section{PHARMACOLOGICAL PROFILES OF COUMARINS}

Over the last two centuries, several coumarin derivatives have become drugs and several are on their way to clinics (Table 1). 
TABLE I. COUMARIN DERIVATIVES AS DRUGS OR ON THEIR WAY TO CLINICS.

\begin{tabular}{|c|c|c|c|c|}
\hline Coumarin & Time & Author & Structure & $\begin{array}{l}\text { Pharmacological } \\
\text { Activity }\end{array}$ \\
\hline 1 & 1954 & $\begin{array}{l}\text { Holford, } \\
\text { Nicholas HG }\end{array}$ & & Anticoagulant [27] \\
\hline 2 & 2009 & $\begin{array}{l}\text { Goldfarb, } \\
\text { David Scott }\end{array}$ & & Anticoagulant [28] \\
\hline 3 & 1974 & $\begin{array}{l}\text { Kiangsu } \\
\text { Luminescent } \\
\text { Bacteria } \\
\text { Research } \\
\text { Unit }\end{array}$ & & Antibiotics [29] \\
\hline 4 & 1931 & $\begin{array}{l}\text { S. Bonfils, } \\
\text { G. Madesclaie }\end{array}$ & & $\begin{array}{l}\text { Choleretic and } \\
\text { antispasmodic [30] }\end{array}$ \\
\hline 5 & 1966 & O. Kraupp, et al. & & Coronary disease [31] \\
\hline 6 & 1957 & $\begin{array}{l}\text { Enders, } \\
\text { Edgar }\end{array}$ & & Anti-HIV activity [32] \\
\hline 7 & 1958 & $\begin{array}{l}\text { Uvarov, Olga } \\
\text { Assignee }\end{array}$ & & Antibiotic [33] \\
\hline 8 & 2014 & B. Xu, L. Wang & & Antiviral activity [6] \\
\hline 9 & 1960 & $\begin{array}{l}\text { Lerchen, } \\
\text { Hans-Georg }\end{array}$ & & $\begin{array}{l}\text { Topoisomerase } \\
\text { inhibitors [34] }\end{array}$ \\
\hline 10 & 1928 & $\begin{array}{l}\text { N. M. Dean, } \\
\text { M. Kanemitsu, } \\
\text { A. L. Boynton }\end{array}$ & & $\begin{array}{l}\text { Genistein influences } \\
\text { mul-tiple biochemical } \\
\text { functions in living cells } \\
\text { [35] }\end{array}$ \\
\hline 11 & 1955 & Hoekserma, et al & & Antibiotics [33] \\
\hline
\end{tabular}

\section{CONCLUSIONS}

In this review, we show all the classical synthetic methods of coumarins, of which, two reactions, Knoevenagel, Peckmann, have higher frequency used for synthesis of coumarins; and also pharmacological profiles of coumarins with various bioactivities, in particular, their physiological, bacteriostatic and antitumor activities. Some compounds were proposed as clinical therapeutic agents. We have made our efforts to compile most of these classical methods and enumerate several important compounds used in clinic and on their way to clinics in the history of exploiting coumarins, which provides an important reference for further research on coumarins.

\section{ACKNOWLEDGMENT}

Financial support from Zhejiang Provincial Natural Science Foundation of China (LY12B02019), and the Program for Zhejiang Leading Team of Science and Technology Innovation (2011R50021). 


\section{REFERENCES}

[1] A. Estévez-Braun and A.G. González, "Coumarins", Natural Product Reports, vol. 14, 1997, pp. 465-475, doi: 10.1039/NP9971400465

[2] V. Malikov, A. Saidkhodzhaev and K.N. Aripov, "Coumarins: plants, structure, properties", Chemistry of Natural Compounds, vol. 34, 1998, pp. 202-264, doi : 10.1007/BF02249149

[3] R.D.H. Murray. Naturally occurring plant coumarins . Springer, 1978.

[4] S.J. Lee, U.S. Lee, W.J. Kim and S.K. Moon, "Inhibitory effect of esculetin on migration, invasion and matrix metalloproteinase-9 expression in TNF- $\alpha$-induced vascular smooth muscle cells", Molecular medicine reports, vol. 4, 2011, pp. 337-341, doi: $10.3892 / \mathrm{mmr} .2011 .420$

[5] D.A. Ostrov, J.A.H. Prada, P.E. Corsino, K.A. Finton, N. Le and T.C. Rowe, "Discovery of novel DNA gyrase inhibitors by highthroughput virtual screening", Antimicrobial Agents and Chemotherapy, vol. 51, 2007, pp. 3688-3698, doi: 10.1128/AAC.00392-07

[6] B. Xu, L. Wang, L. Gonzalez-Molleda, Y. Wang, J. Xu and Y. Yuan, "Antiviral Activity of (+)-Rutamarin against Kaposi's SarcomaAssociated Herpesvirus by Inhibition of the Catalytic Activity of Human Topoisomerase II", Antimicrobial Agents and Chemotherapy, vol. 58, 2014, pp. 563-573, doi: 10.1128/Aac.01259-13.

[7] I. Kostova, S. Bhatia, P. Grigorov, S. Balkansky, V. S Parmar, A. K Prasad, et al., "Coumarins as antioxidants", Current Medicinal Chemistry, vol. 18, 2011, pp. 3929-3951, doi: http://dx.doi.org/10.2174/092986711803414395

[8] P. Anand, B. Singh and N. Singh, "A review on coumarins as acetylcholinesterase inhibitors for Alzheimer's disease", Bioorganic \& Medicinal Chemistry, vol. 20, 2012, pp. 1175-1180, doi:10.1016/j.bmc.2011.12.042

[9] X.Y. Huang, Z.J. Shan, H.L. Zhai, L. Su and X.Y. Zhang, "Study on the anticancer activity of coumarin derivatives by molecular modeling", Chemical Biology \& Drug Design, vol. 78, 2011, pp. 651-658, doi: 10.1111/j.1747-0285. 2011.01195.x

[10] J.F. Vasconcelos, M.M. Teixeira, J.M. Barbosa-Filho, M.F. Agra, X.P. Nunes, A.M. Giulietti, et al, "Effects of umbelliferone in a murine model of allergic airway inflammation", European Journal of Pharmacology, vol. 609, 2009, pp. 126-131, doi:10.1016/j.ejphar.2009.03.027

[11] K.V. Sashidhara, R.K. Modukuri, S. Singh, K.B. Rao, G.A. Teja, S. Gupta, et al., "Design and synthesis of new series of coumarinaminopyran derivatives possessing potential anti-depressant-like activity", Bioorganic \& Medicinal Chemistry Letters, vol. 25, 2015, pp. 337-341, doi:10.1016/j.bmcl.2014.11.036

[12] Y. Kashman, K.R. Gustafson, R.W. Fuller, J.H. Cardellina, J.B. McMahon, M.J. Currens, et al., "HIV inhibitory natural products. Part 7. The calanolides, a novel HIV-inhibitory class of coumarin derivatives from the tropical rainforest tree, Calophyllum lanigerum", Journal of Medicinal Chemistry, vol. 36, 1993, pp. 1110-1110, doi: 10.1021/jm00093a004

[13] A. Manvar, A. Bavishi, A. Radadiya, J. Patel, V. Vora, N. Dodia, et al., " Diversity oriented design of various hydrazides and their in vitro evaluation against Mycobacterium tuberculosis $\mathrm{H} 37 \mathrm{Rv}$ strains ", Bioorganic \& Medicinal Chemistry Letters, vol. 21, 2011, pp. 4728-4731, doi: $10.1021 /$ co4001259

[14] J.Y. Yeh, M.S. Coumar, J.T. Horng, H.Y. Shiao, F.M. Kuo, H.L. Lee, et al., "Anti-Influenza Drug Discovery: Structure- Activity Relationship and Mechanistic Insight into Novel Angelicin Derivatives", Journal of Medicinal Chemistry, vol. 53, 2010, pp. 1519-1533, doi: 10.1021/jm901570x

[15] [15] G.R. Madhavan, V. Balraju, B. Mallesham, R. Chakrabarti and V.B. Lohray, "Novel coumarin derivatives of heterocyclic compounds as lipid-lowering agents", Bioorganic \& Medicinal Chemistry Letters, vol. 13, 2003, pp. 2547-2551, doi:Doi 10.1016/S0960-894x(03)00490-6.

[16] R.H. Vekariya and H.D. Patel, "Recent Advances in the Synthesis of Coumarin Derivatives via Knoevenagel Condensation: A Review", Synthetic Communications, vol. 44, 2014, pp. 27562788,doi:10.1080/00397911.2014.926374
[17] W. Perkin, "On the artificial production of coumarin and formation of its homologues", Journal of the Chemical Society, vol. 21, 1868, pp. 53-63, doi:10.1039/JS8682100053

[18] V.K. Ahluwalia, D. Singh and R.P. Singh, "A facile synthesis of 4aryl-2H-1-benzopyran-2-ones", Monatshefte für Chemie/Chemical Monthly, vol. 116, 1985, pp. 869-872, doi:10.1007/BF00809163

[19] H.v. Pechmann and N.B. Cumarine, Synthese des Daphnetins ", Ann Chemical and Pharmaceutical, vol. 147, 1884, pp. 229, doi: $10.1002 /$ cber. 188401701248

[20] E. Rizzi, S. Dallavalle, L. Merlini, G. Pratesi and F. Zunino, "Short Synthesis of Cytotoxic 4-Arylcoumarins", Synthetic Communications, vol. 36, 2006, pp. 1117-1122, doi:10.1080/00397910500501235

[21] K. Sato and T. Amakasu, "Coumarins. V. Acid-catalyzed reaction of phenols with. beta.-oxonitriles", The Journal of Organic Chemistry, vol. $33, \quad 1968$, pp. 2446-2450, doi:10.1021/jo01270a060

[22] P.T. Kaye and M.A. Musa, "A Convenient and Improved BaylisHillman Synthesis of 3-Substituted2H-1-benzopyran-2-ones ", Synthesis, vol.18, 2002, pp. 2701-2706, doi :10.1055/s-200235984

[23] Y. Fall, C. Teran, M. Teijeira, L. Santana and E. Uriarte, "Synthesis of new 4-cyclohexylcoumarin derivatives", Synthesis, vol. 5, 2000, pp. 643-645, doi :10.1055/s-2000-6395

[24] R.L. Shriner, "The reformatsky reaction", Organic reactions, vol. 1942, pp. 1-37, doi: 10.1002/0471264180.or001.01

[25] S. Ghantwal and S. Samant, "Claisen rearrangement of 3-bromo-3, 6-dibromo-3, 8-dibromo-and 8-iodo/aminomethyl/acetyl-7allyloxy-4-methylcoumarins", Indian Journal of Chemistry Section, vol. 38, 1999, pp. 1242-1247.

[26] F. Bourgaud, A. Hehn, R. Larbat, S. Doerper, E. Gontier, S. Kellner, et al., "Biosynthesis of coumarins in plants: a major pathway still to be unravelled for cytochrome P450 enzymes", Phytochemistry Reviews, vol. 5, 2006, pp. 293-308, doi : 10.1007/s11101-006-9040-2

[27] N.H. Holford, "Clinical pharmacokinetics and pharmacodynamics of warfarin", Clinical pharmacokinetics, vol. 11, 1986, pp. 483504, doi :10.2165/00003088-198611060-00005

[28] D. Goldfarb, Method using lifespan-altering compounds for altering the lifespan of eukaryotic organisms, and screening for such compounds, US Pat Appl Publ US2009163545 A, vol. 1, 2009, pp. 20090625.

[29] Y. Wang, Y. Wang, P. Li, Y. Tang, J.P. Fawcett and J. Gu, "Quantitation of Armillarisin A in human plasma by liquid chromatography-electrospray tandem mass spectrometry", Journal of Pharmaceutical and Biomedical Analysis, vol. 43, 2007, pp. 1860-1863, doi :10.1016/j.jpba.2006.12.023

[30] S. Bonfils and G. Madesclaire, Emploi de Pelectromanometrie chez Phomme cholecystectomise pour Petude de substances choleretiques et anttspasmodiques biliaires, vol. 22. Therapie,1967, pp. 521.

[31] O. Kraupp, E. Wolner and J. Suko, Die Wirkung von Langzeitcoronardilatatoren am reserpinisierten Hund", NaunynSchmiedebergs Archiv für Pharmakologie und experimentelle Pathologie, vol. 254, 1966, pp. 431-438,

[32] D.J. Anderson, P.A. Aristoff, L.S. Banitt, M.J. Bohanon, G.L. Bundy, R.B. Gammill, et al. 4-hydroxy-benzopyran-2-ones and 4hydroxy-cycloalkyl b! pyran-2-ones useful to treat retroviral infections [M]. Google Patents. 1997.

[33] H. Hoeksema, J.L. Johnson and J.W. Hinman, " Structural studies on streptonivicin, a new antibiotic ", Journal of the American Chemical Society, vol. 77, 1955, pp. 6710-6711, doi : $10.1021 / \mathrm{ja} 01629 \mathrm{a} 129$

[34] H.G. Lerchen, "Milestones in camptothecin research", Drugs of the Future, vol. 27, 2002, pp. 869-876, doiv : 10.1358/dof.2002.027.09.694498

[35] N.M. Dean, M. Kanemitsu and A.L. Boynton, "Effects of the tyrosine-kinase inhibitor genistein on DNA synthesis and phospholipid-derived second messenger generation in mouse 10T1/2 fibroblasts and rat liver T51B cells", Biochemical and Biophysical Research Communications, vol. 165, 1989, pp. 795 801, doi :10.1016/S0006-291X(89)80036-1 